\title{
Policy Response and Collaboration in Handling Covid-19 in East Kutai Regency With An Adaptive Governance Approach in Disasters
}

\author{
Aji Ratna Kusuma ${ }^{1^{*}}$ and Paisal Akbar ${ }^{2}$ \\ ${ }^{1}$ Master of Public Administration, Universitas Mulawarman, Jl. Muara Muntai Kampus Gunung Kelua \\ 75411, Samarinda, Indonesia \\ ${ }^{2}$ Doctoral Program in Political Islam-Political Science, Jusuf Kalla School of Government, \\ Muhammadiyah University of Yogyakarta, JL. Brawijaya, Kasihan, Bantul, 55183, Yogyakarta, \\ Indonesia
}

How to cite: Kusuma, Aji Ratna \& Akbar, Paisal. (2021). Policy Response And Collaboration In Handling Covid-19 In East Kutai Regency With An Adaptive Governance Approach In Disaster. Jurnal Borneo Administrator, 17 (2), 223-240. https://doi.org/10.24258/jba.v17i2.866

\section{Article History}

Received: 15 March 2021

Accepted: 14 July 2021

\section{Keywords:}

Collaboration

Policy response

COVID-19

Adaptive Governance

\begin{abstract}
The current COVID-19 pandemic condition requires the Indonesian government to act quickly and effectively in dealing with the threat of a crisis; for this reason, the concept of adaptive governance promises a more innovative approach in an effective way to deal with a complex environment. Adaptation in governance is carried out by producing policy products that are swift, efficient, and effective in handling the COVID-19 pandemic. This research aims to find out how the local government of East Kutai Regency applies the concept of adaptive governance with the scope of policies and collaboration between parties in handling the COVID-19 Pandemic. The benefits of research will fill the space for scientific studies related to adaptive governance approaches in handling pandemics through policy products and collaboration between parties within the most basic scope, namely the East Kutai Regency level. This research is qualitative research with the descriptive method; the approach used in this research is a case study approach. For research data analysis, this study used Qualitative Data Software Analysis (QDSA) NVivo 12 Plus. The study results show that the five agencies have carried out their roles to provide adaptive governance. Of the six indicators, each agency has a different percentage level. There are tons of steps that have been taken to prevent the spread and handling of COVID-19 by the government and agencies, as well as layers of society. The involvement of Task Force Teams at all levels, the Police, Military District Commands, Community Organizations, NGOs, and Companies in assisting the prevention and handling of the COVID-19 pandemic running the East Kutai District Health Office shows a form of participation and collaboration in handling the COVID-19 pandemic health disaster. Which is an essential value in realizing adaptive governance.
\end{abstract}

\section{A. INTRODUCTION}

The year 2020 is a historic year for human life, not because of the pen of a happy history but the irony of a pen of history full of fear, sorrow, and death. Occurring evenly throughout

\footnotetext{
* Corresponding Author

Email : ajiratnakusuma@fisip.unmul.ac.id
} 
the world (Chen et al., 2020), Coronavirus Disease (COVID-19) is present and becomes a deadly outbreak. Recorded, the entire country's total cases on February 24, 2021, COVID-19 has infected 112,774,854 people on earth and resulted in 2,499,111 deaths of the exposed victim (Worldmeter, 2021). COVID-19 is the first pandemic in the modern era that impacts many human life sectors ranging from social, economic, political, educational, and other activities that require social interaction must be stopped and limited (Hadiwardoyo, 2020; Junaedi et al., 2020; Khan et al., 2021; Nasruddin \& Haq, 2020; Syah, 2020).

Referring Graph 1 shows that Indonesia's position is ranked 18th in the world as a country with the total number of COVID-19 cases reaching 1,306,141 cases. Meanwhile, when viewed more regionally in Asia, Indonesia ranks 4th as the country with the highest cases. It is the country in the Southeast Asia region with the highest cases of COVID-19. Graph 1. The Total Number of COVID-19 Cases in the World and Asia by Country
Reported Cases Covid-19 by Country

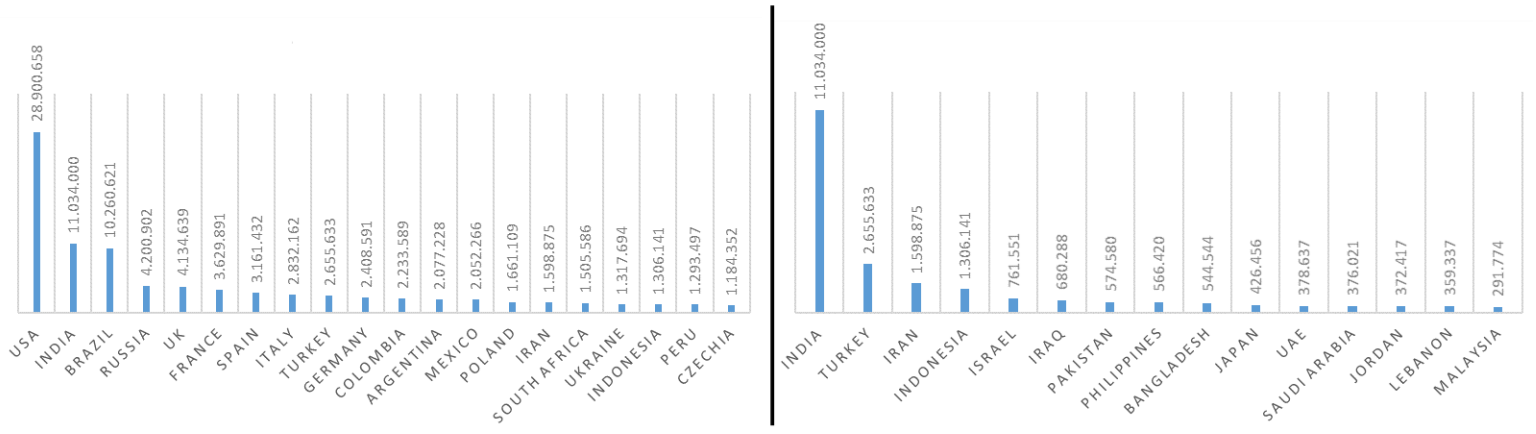

Source: Worldmeter (2021)

With a total area of 7.81 million $\mathrm{km}^{2}$ and 17,499 islands (Pratama, 2020), the picture of the complexity of mitigating the COVID-19 pandemic in such a large area is easily illustrated and is a real challenge and must be faced by all government stakeholders in Indonesia (Olivia et al., 2020; Samudro \& Madjid, 2020). There is an unfair side if we compare the successful handling of the COVID-19 in Singapore with the span of a total area of only $722.5 \mathrm{~km} 2$ by comparing COVID-19 in Indonesia, which has a large area and a much larger population than Singapore, Malaysia, and Vietnam.

Therefore, the Indonesian government, in handling the COVID-19 pandemic, must formulate the appropriate policy products to handle the spread of COVID-19 and maintain the health, social, and economic stability of the people in Indonesia at the same time (Junaedi et al., 2020; Shahbudin, 2020; Tuwu, 2020). Adaptation in governance is an important thing that must carry out by producing swift, efficient, and practical policy products in handling the COVID-19 pandemic (Janssen \& van der Voort, 2020; Telaumbanua, 2020).

Adaptive governance was proposed as an alternative method in managing complex social-environmental problems, including, in this case, related to disaster situations (Brunner, 2010; Djalante, 2012). The current pandemic situation requires the Indonesian government to act quickly and effectively in dealing with the threat of a crisis, which is why the concept of adaptive governance promises a more innovative approach in an effective way to deal with a complex environment (Holley, 2010).

In addition to the central government's role, the handling of the COVID-19 pandemic is also the jurisdiction of the local government (Syafrida, 2020). The involvement of local governments in mitigating the handling of COVID-19 is inextricable. With Indonesia's vast area so large, the handling of zoning per region becomes a decent thing to run. The implementation of Large-Scale Social Restrictions (called PSBB) is one of the policy products that the Government of Indonesia has implemented in many regions to handle the 
spread of COVID-19 in the area (Handayanto \& Herlawati, 2020; Putsanra, 2020; Saputra \& Salma, 2020).

The importance of local governments' role in handling the COVID-19 pandemic is inseparable; a collaboration of all relevant parties in handling is one of the keys to success to reduce the spread of the COVID-19 virus (Syafrida, 2020). For this reason, this research will look at how to mitigate the handling of the COVID-19 virus at the lowest level in one of the regencies in East Kalimantan Province, namely the East Kutai Regency. This research aims to find out how the local government of East Kutai Regency applies the concept of adaptive governance with the scope of policies and collaboration between parties in handling the COVID-19 Pandemic.

\section{B. LITERATURE REVIEW}

Adaptive governance is an approach used to address complex obstacle situations that occur in the field involving many stakeholders with different interests resulting in inaccuracies in determining the actions to be taken (Janssen \& van der Voort, 2016). Furthermore, according to Huitema et al. (2009), adaptive governance is a step to overcome uncertainties caused by complexity, spontaneity, non-reduction, variability, and the quality of collaborative ecosystems.

To lead to the concept of adaptive, effective governance, it can realize if there is a robust interrelated relationship between science, governance, and practice (Wyborn, 2015). The previous researchers have widely done the literature on disaster mitigation with the application of adaptive governance as a solution in disaster management; these studies have currently provided a basis for researchers to describe and classify the concept of adaptive governance in the face of a series of interactions between actors, networks, organizations, and institutions that arise in pursuit of the desired circumstances in a condition (Chaffin et al., 2014).

The following is some literature of previous studies that discuss related disaster mitigation with an adaptive governance approach.

Table 1. Literature Review Related to Adaptive Governance in Disaster Mitigation

\begin{tabular}{|c|c|c|}
\hline No & Authors \& Titles & Focus \\
\hline \multicolumn{3}{|c|}{ Lei et al., (2015), } \\
\hline 1 & $\begin{array}{l}\text { Adaptive governance to } \\
\text { typhoon disasters for } \\
\text { coastal sustainability: A } \\
\text { case study in Guangdong, } \\
\text { China }\end{array}$ & $\begin{array}{l}\text { Adaptive typhoon disaster } \\
\text { management in Guangdong, } \\
\text { China }\end{array}$ \\
\hline
\end{tabular}

\section{Aoki (2016),}

2 Adaptive governance for resilience in the wake of the 2011 Great East Japan Earthquake and Tsunami
It was investigating the 2011 Great East Japan Earthquake and Tsunami that impacted governance.
Structural action in disaster management is not enough; in disaster mitigation, typhoons require non-structural actions and resilience development by putting forward the concept of adaptive governance; adaptive governance is carried out through multi-stakeholder participation and vertical-horizontal coordination.

Through a polycentric government, the Japanese system created various institutional governance arrangements created to respond to labor shortages in municipal government offices and organizations/institutions. This experience shows that decentralized disaster governance and ready to mobilize a polycentric governance system will manage disasters well.

Catastrophic climate change conditions, drought, and flooding can be better 
Adaptive Governance, adaptation to develop responded to when the resulting policy Uncertainty, and Risk: policies for disaster relationships are interconnected. The Policy Framing and management of climate problems found can be framed through Responses to Climate change, drought, and policies that result in a better Change, Drought, and floods. understanding of adaptive governance.

Flood

Smith \& Lawrence (2018),

From disaster management

4. to adaptive governance, Governance challenges to achieving resilient food systems in Australia
How governance arrangements and processes affect the involvement of food system actors.
Molenveld \& van Buuren (2019),

5. Flood Risk and Resilience in the Netherlands: In Search of an Adaptive Governance Approach
The Dutch introduced more polycentric and adaptive governance in flood management, which they term multilayered safety (MLS).

Although there have been standard rules through formal governance instruments that upheld in the implementation of governance in disaster management. However, still, the use of roles is not well understood. Food availability responsibilities are still borne by supermarkets, which do not make room for a non-supermarket food system. The policy challenge is to ensure that responsibility, participation, and collaboration become a stronger focus for adaptive governance during and after disasters.

Flood management with an adaptive and polycentric governance approach is considered capable of presenting good flood disaster management. Although many governments face rejection by a small network of water experts and permanent institutionalists, adaptive and polycentric new policies deliver the desired results.

The implementation of adaptive

Walch (2019),

Adaptive governance in the developing world: disaster risk reduction in the State of Odisha, India
Discussing the case of adaptive governance success in non-western developing countries, namely India, focusing on Odisha State.

\section{Ruane (2020)}

Applying the principles of

7. adaptive governance to bushfire management: a case study from the South West of Australia

\section{Janssen \& van der Voort}

$$
\text { (2020), }
$$

8. Agile and adaptive governance in crisis response: Lessons from the COVID- 19 pandemic
Khan et al. (2021), An adaptive governance and health system responsible for the COVID-19 emergency
Adaptive governance in tackling the socioecological problems of bushfires in south-west Australia

Disaster management of the COVID-19 pandemic in the Netherlands by analyzing agility and adaptive governance approaches. governance is based on two main factors. First, traumatic shock factors in the form of shocks that occur at society's economic and social levels. Second, the shock factor of political leadership committed to reforming existing governance and creating a more resilient system.

The findings suggest that the current disaster policy discourse in Australia has supported the principle of adaptive governance. However, its implementation in some regions depends on the definition of the policy framework implemented in the region.

Existing structures and devices can contribute to implementation that enables adaptation and agility. However, on the other hand, there is a conflict between adaptability and agility. Institutional efforts are needed to facilitate adaptive governance in the long term. In handling the COVID-19 pandemic disaster in Bangladesh, appropriate response strategies are needed. The optimal strategy is to filter the most viable range of health response networks as well as organization networks that can provide the most effective results on a massif scale, which is why adaptive response strategies are needed to align the network of old 
organizations and new organizational networks in the handling of the COVID-19 pandemic.

Source: Processed By The Author

Based on the literature review above, adaptive governance is critical in implementing effective and efficient disaster management. Rijke et al. (2012) are of the view that to realize adaptive governance, and a basic assessment is needed that pays more attention to "good enough governance" rather than towards "optimal governance", is because, in its implementation, the concept of adaptive governance will be found the uncertainty requires action that focuses on important things by making adjustments to share priorities in the short and long term, feasibility, and whether or not a goal is realistic to be achieved through the resulting policies (Grindle, 2004; Rijke et al., 2012).

Various approaches are needed to measure adaptive governance achievement that becomes the initial benchmark for the final value of adaptive governance performance. Rijke et al. (2012) introduced a "fit-for-purpose" framework consisting of three main parts: developing a diagnostic approach to describe an adaptive governance operation. There are three essential steps in diagnosing fit-for-purpose governance mechanisms: (1) identifying the governance objectives, (2) mapping the context, and (3) evaluating the outcomes of the governance mechanisms (Rijke et al., 2012).

The involvement of various elements in handling is necessary, meaning that not only formal regulations governing disaster management are needed but also high agility and adaptability to all relevant stakeholders for post-disaster recovery to be more optimal (Khan et al., 2021; Lei et al., 2015; Ruane, 2020; Smith \& Lawrence, 2018). Hasselman (2017), adaptive governance combines adaptive management through democratic institutions, polity, and policy facets of governance, with the consequences for credibility and transparency discussed by the systems and agents in place.

\section{METHOD}

This research is qualitative research with the descriptive method; the approach used in this study is the case study approach. According to Creswell \& Poth (2016) and Al-Hamdi et al. (2020), the case study approach's feature is that the case studied must have specific parameters such as place or time and provide a deep understanding of the case study. The location of the research was conducted in East Kutai Regency, East Kalimantan Province. Data collection in this study using two data sources, namely primary and secondary data; primary data is data obtained by researchers in interviews with related parties in handling the COVID-19 pandemic in East Kutai Regency. Some of the parties interviewed in this study can be seen in the following table.

Table 2. Key Informant

\begin{tabular}{cl}
\hline No & \multicolumn{1}{c}{ Sources } \\
\hline 1 & $\begin{array}{l}\text { Regional Disaster Management Agency (called BPBD) East Kutai } \\
\text { Regency }\end{array}$ \\
\hline 2 & East Kutai District Health Office \\
\hline 3 & East Kutai District Transportation Office \\
\hline 4 & Social Service of East Kutai Regency \\
\hline 5 & Community \& Village Empowerment Office \\
\hline Source: Processed by Author
\end{tabular}

Meanwhile, the researchers from available literature obtained secondary data such as government websites, online news media, government reports, and publications of previous 
scientific articles. This study used Qualitative Data Software Analysis (QDSA) NVivo 12 Plus to analyze research data. NVivo 12 Plus is a software that can help researchers provide greater understanding through a more in-depth analysis of the study findings (Andrew et al., 2008; Edwards-Jones, 2014; Muhtarom et al., 2017), this is the function of this software. Nvivo 12 plus software allows the researchers to code interview transcripts based on the research indicators (Ruane, 2020). The use of NVivo as an analysis tool has stages that begin with; (1) data capture, (2) data import, (3) data coding, (4) data classification, and (5) data presentation (Brandão, 2015; Loilatu et al., 2021).

By presenting the resulting data in the form of word cloud analysis and connectivity between stakeholders responsible for handling the COVID-19 pandemic, it will provide a good understanding of the extent of policy response and collaboration in handling COVID-19 in District East Kutai. The used coding of data in this study utilized open coding by identifying the keywords, phrases, or sentences contained in the interview transcript. According to the indicators used, data coding was determined: Prevention, Handling, Adaptation, Agility, Organizational Networks, and Supportive Relationships. The stages of data analysis in this study can be seen in the following figure:

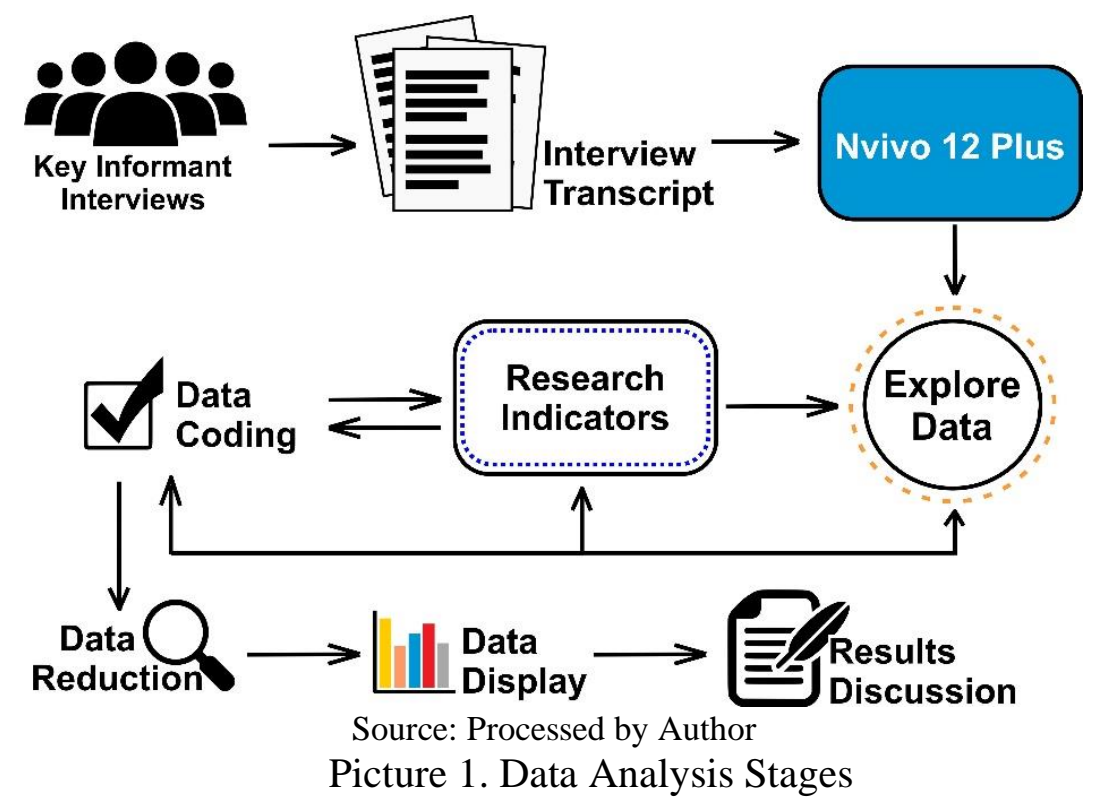

\section{RESULTS AND DISCUSSIONS}

\section{Regional Profile and Distribution of Health Facilities in East Kutai Regency}

East Kutai Regency is an expansion district of Kutai Regency, which is determined based on Law No. 47 of 1999 concerning the expansion of provincial and district areas as well as the decision of the Minister of Home Affairs dated October 28, 1999 (Pemkab. Kutai Timur, 2021). The area of East Kutai Regency covers $35,747.50 \mathrm{~km}^{2}$ or $17 \%$ of the total area of East Kalimantan Province today; the geographical condition of East Kutai Regency consists of a land area of 536,200 ha, mountains of 1.42 million ha, sea/coastal waters, and rivers and lakes (Pemkab. Kutai Timur, 2021). Administratively, East Kutai Regency is divided into 18 sub-districts (see Picture 2) with 141 villages and has about 434,459 people (BPS Kutai Timur, 2021; DPMPTSP Kabupaten Kutai Timur, 2021). 


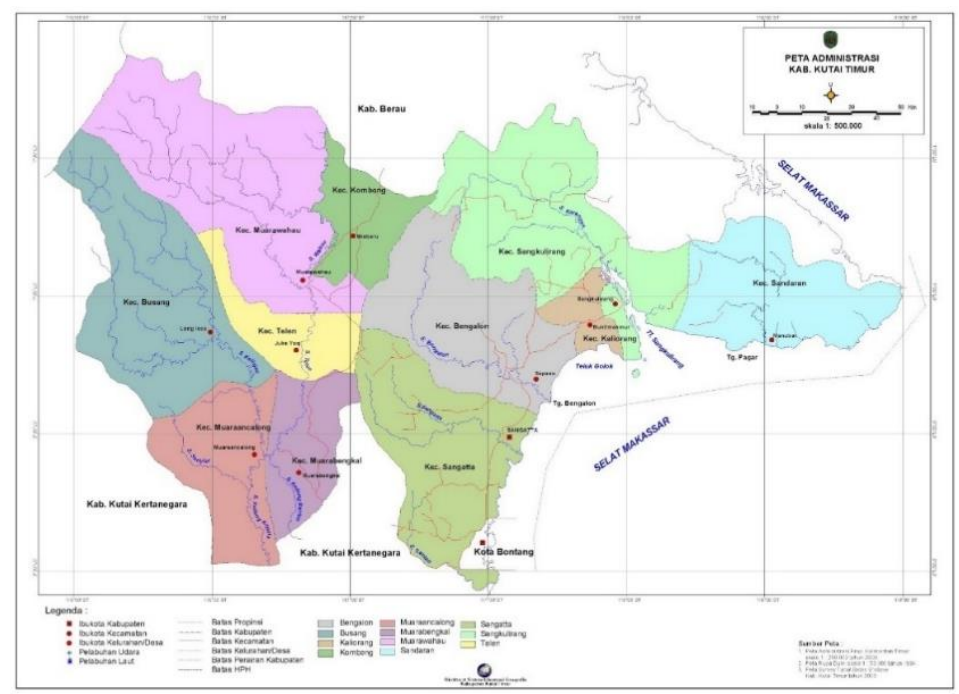

Photo: DPMPTSP Kabupaten Kutai Timur (2021)

Picture 2. Map of East Kutai Regency

East Kutai Regency's health condition is an inseparable part of population welfare indicators (BPS Kutai Timur, 2019). The percentage development of people who have health complaints in the East Kutai Regency has increased in 2019/2020 (BPS Kutai Timur, 2019). This increasing percentage is inseparable from the health crisis that occurred in the early 2020 pandemic COVID-19. Health facilities and infrastructure are essential in providing inclusive health services to all communities in East Kutai Regency. An overview of the distribution of health infrastructure facilities owned by East Kutai Regency's government can be seen in table 3 .

Table 3. Health Facilities in East Kutai Regency

\begin{tabular}{|c|c|c|c|c|c|c|}
\hline No & District & Hospital & $\begin{array}{c}\text { Public Health } \\
\text { Center }\end{array}$ & $\begin{array}{c}\text { Maid Public Health } \\
\text { Center }\end{array}$ & Clinic & $\begin{array}{r}\text { Maternity } \\
\text { Hospital }\end{array}$ \\
\hline 1 & Muara Ancalong & - & 1 & 6 & 1 & - \\
\hline 2 & Busang & - & 1 & 4 & 2 & - \\
\hline 3 & Long Mesangat & - & 1 & 7 & - & - \\
\hline 4 & Muara Wahau & - & 2 & 6 & 4 & - \\
\hline 5 & Telen & - & 1 & 6 & - & - \\
\hline 6 & Kongbeng & - & 1 & 7 & 2 & - \\
\hline 7 & Muara Bengkal & - & 1 & 5 & 1 & 2 \\
\hline 8 & Batu Ampar & - & 1 & 6 & - & - \\
\hline 9 & Sangatta Utara & 2 & 2 & 1 & 4 & 2 \\
\hline 10 & Bengalon & 1 & 2 & 6 & 1 & - \\
\hline 11 & Teluk Pandan & 1 & 1 & 5 & 2 & - \\
\hline 12 & Sangatta Selatan & - & 1 & 4 & 2 & - \\
\hline 13 & Rantau Pulung & - & 1 & 7 & - & - \\
\hline 14 & Sangkulirang & - & 1 & 15 & 3 & - \\
\hline 15 & Kaliorang & - & 1 & 4 & - & - \\
\hline 16 & Sandaran & - & 1 & 8 & 2 & - \\
\hline 17 & Kaubun & - & 1 & 7 & 1 & - \\
\hline 18 & Karangan & - & 1 & 6 & 1 & - \\
\hline & Total & 4 & 21 & 110 & 26 & 4 \\
\hline
\end{tabular}

Source: BPS Kutai Timur (2021)

From the table, it can be seen that the distribution of health facilities and infrastructure in East Kutai Regency is evenly distributed with the availability of primary health facilities, 
namely Public Health Center (called Puskesmas) in all sub-districts in East Kutai Regency. Puskesmas is one of the agencies engaged in public health services; Puskesmas has a responsibility to realize the quality of health in the region, which includes four leading indicators, namely healthy relationships, healthy behaviors, quality health services, and improving the quality of health of the population (Cahyanti \& Purnama, 2017; Handayani, 2016). In addition to the spread of Puskesmas evenly, East Kutai Regency has also had four hospital health facilities distributed in three sub-districts, four of which later became COVID19 patient referral hospitals in East Kutai Regency.

\section{COVID-19 in East Kutai Regency}

The spread of COVID-19 in East Kalimantan Province is still occurring, recorded on March 1, 2021 update infographic COVID-19 in East Kalimantan Province showed positive case confirmation as many as 55,828 details of patients treated as many as 6,855, patients recovered 47,654 cases. Patients died 1,319 cases (covid19.kaltimprov.go.id, 2021). The high number of cases in East Kalimantan province shows an increasing movement. East Kutai Regency, as one of the regions in East Kalimantan Province, also has a positive confirmation case rate that occupies the 4th position as the Regency/City with the most positive confirmation cases in East Kalimantan Province of nine districts/cities (covid19.kaltimprov.go.id, 2021). Picture 3 shows the total positive cases of COVID-19 in East Kutai Regency, as many as 7,309 cases.

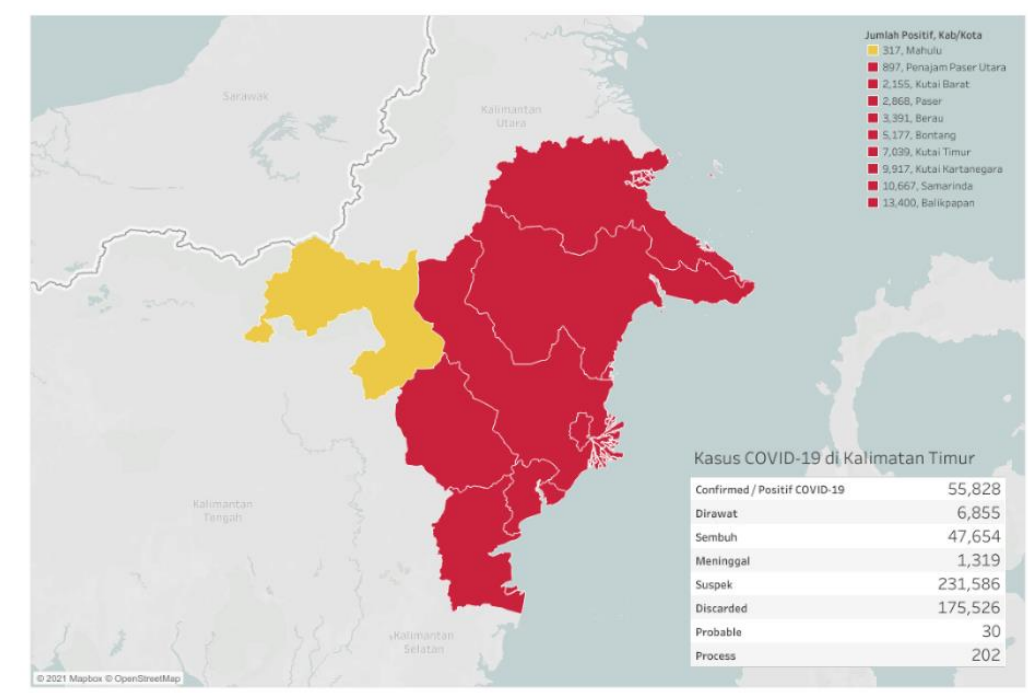

Photo: covid19.kaltimprov.go.id (2021)

Picture 3. COVID-19 Monitoring Map in East Kalimantan Province

In many cases, almost all regions in East Kalimantan Province occupy the position as a red zone for the spread of COVID-19. According to Doni Monardo, head of the Task Force on The Acceleration of COVID-19 Handling, the Red Zone category of COVID-19 spread is the category of areas with a high-risk COVID-19 transmission. In contrast, the Yellow Zone category is an area with a low risk of COVID-19 transmission (Kementrian Kesehatan RI, 2020a, 2020b). Based on Picture 3, in addition to showing the number of COVID-19 spread in East Kalimantan Province, it also shows the category of zones owned by each District/City. Nine of the ten regencies/cities in East Kalimantan are listed as areas classified as Red Zones, including East Kutai Regency. There is only one area that is still classified as a Yellow Zone, namely Mahakam Ulu Regency. 
In contrast to the COVID-19 Monitoring Map of East Kalimantan Province, which depicts most of the region is within the Red Zone. At the national level, through the update of the COVID-19 Risk Map from the web portal: Covid19.go.id (2021) of the Task Force on Handling COVID-19 as well as the Committee for Handling COVID-19 and National Economic Recovery shows the position of the risk of the spread of COVID-19 in the province of East Kalimantan categorize Medium Risk, indicated by the identification of the color "orange" in picture 4. All regencies/cities in East Kalimantan province are categorized as areas at moderate risk in the spread of COVID-19. The regional Risk Zoning Map has been released from the Task Force's calculation on Handling COVID-19 based on public health indicators shown in table 4.

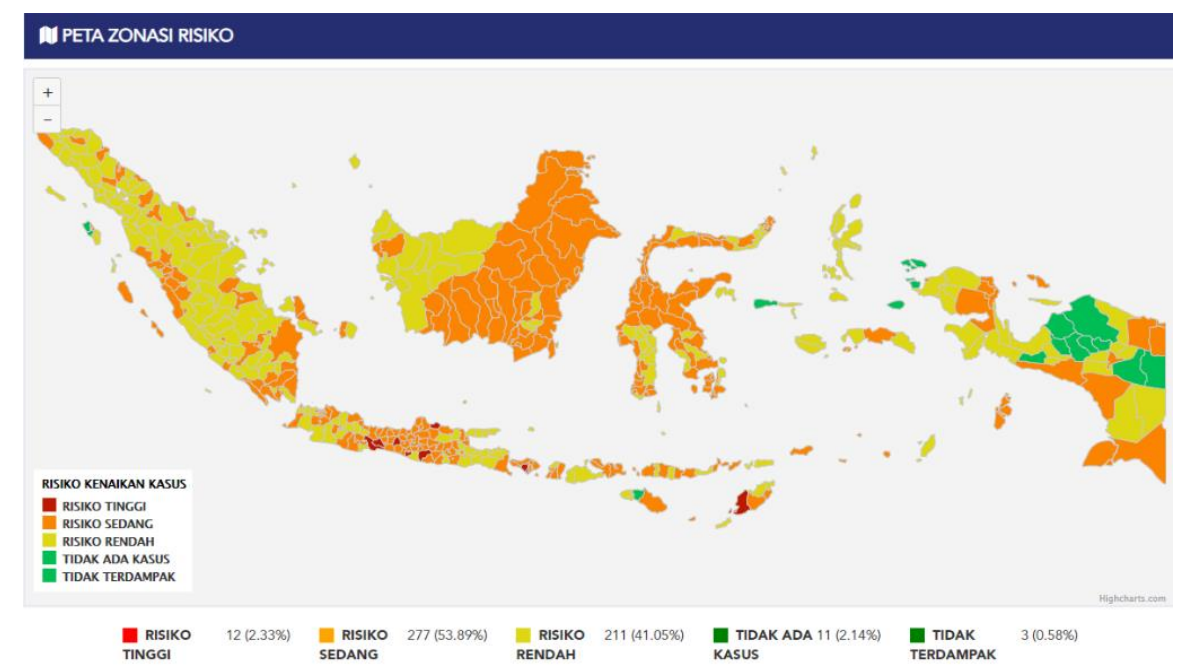

Photo: Covid19.go.id (2021)

Picture 4. COVID-19 Risk Zoning Map

Table 4. Public Health Indicators for COVID-19 Risk Zoning

\begin{tabular}{|c|c|c|}
\hline No & Indicators & Variable \\
\hline 1 & Epidemiological Indicators & $\begin{array}{l}\text { - Decrease in the number of positive \& probable cases in the } \\
\text { last week by } \geq 50 \% \text { from the peak } \\
\text { - } \quad \text { Decrease in the number of suspect cases in the last week by } \\
\geq 50 \% \text { from the peak } \\
\text { - } \\
\text { Decrease in the number of positive \& probable cases died in } \\
\text { the last week by } \geq 50 \% \text { from the peak } \\
\text { - The decrease in the number of deaths in suspect cases in the } \\
\text { last week by } \geq 50 \% \text { from the peak } \\
\text { - } \quad \text { Decrease in the number of positive \& probable cases } \\
\text { hospitalized in the last week by } \geq 50 \% \text { from the peak } \\
\text { - The decrease in the number of hospitalized suspect cases in } \\
\text { the last week by } \geq 50 \% \text { from the peak } \\
\text { - Cumulative percentage of cases recovered from all positive \& } \\
\text { - Probable cases } \\
\text { - Tositive case incidence rate per } 100,000 \text { inhabitants } \\
\text { - Ine mortality rate of positive cases per } 100,000 \text { inhabitants } \\
\text { Incidence Rate Speed per } 100,000 \text { inhabitants }\end{array}$ \\
\hline 2 & $\begin{array}{l}\text { Public Health Surveillance } \\
\text { Indicators }\end{array}$ & $\begin{array}{l}\text { - The number of diagnosis sample examinations has increased } \\
\text { over the past two weeks } \\
\text { - Low positivity rate (target } \leq 5 \% \text { positive sample of all people } \\
\text { examined) }\end{array}$ \\
\hline 3 & Health Care Indicators & $\begin{array}{l}\text { - The number of beds in the isolation room of the Referral } \\
\text { Hospital can accommodate up to } 20 \% \text { of the number of }\end{array}$ \\
\hline
\end{tabular}


COVID-19 positive patients treated in the hospital

- The number of beds in the Referral Hospital can accommodate up to $20 \%$ of the number of ODP, PDP, and COVID-19 positive patients treated in the hospital

\section{Adaptive Governance in Responding to COVID-19}

We have seen the condition of COVID-19 in the East Kutai Regency in the previous section. This section will explain the extent to which the handling of the COVID-19 Pandemic has been carried out by the parties responsible for handling it through adaptive governance. Several adaptive governance elements that became indicators in this study were then searched for their relationship with information from key informants through interviews. After they were found in the process carefully, the researchers in the Nvivo 12 Plus application explored using the Explore Crosstab Query feature. The results of data visualization can be seen in Graph 1 .

Graph 1. The Intensity of Elements of Adaptive Governance in Responding to COVID-19

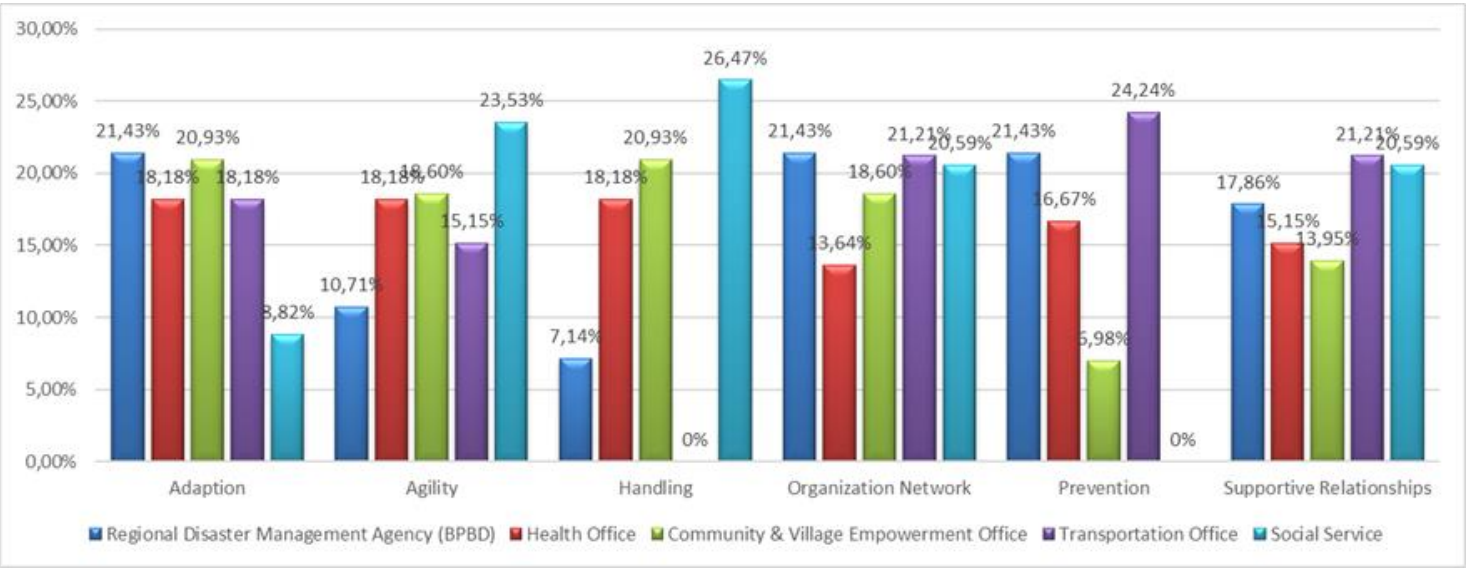

Graph 1 shows the activity of each agency in carrying out its role to provide adaptive governance. Of the six indicators, each agency has a different percentage level. Referring to these data, it can be seen carefully, the Transportation Office agency in the handling of the COVID-19 virus does not show any activities carried out because indeed, the tasks and functions that are carried out tend to be more inclined towards Prevention activities, which shows the highest percentage in the Prevention indicator, namely $24.24 \%$. Meanwhile, Social Service agencies have a level of activity in the Prevention indicator area, but Social Service agencies have the highest level with $26.47 \%$ in the Handling indicator.

The responsible five agencies for handling COVID-19 must carry out their duties and functions well; each agency has carried out the ability to respond to disaster situations quickly through agility. Agility indicators are essential indicators that must be presented in disaster management that require a quick response from stakeholders to save the community. Huitema et al. (2009) dan Janssen \& van der Voort (2020) assess the dexterity of various parties in responding to critical times as crucial. The percentage of agility shown in picture 3 shows that all agencies have a level of agility percentage even though the percentage level is different. Likewise, in the other three indicators: adaptation, organization network, and supportive relationships, overall, the five agencies have them with different percentage levels.

Furthermore, interviews were conducted with research resource persons who were then coded with NVivo 12 plus software and processed in the feature to explore the word cloud results from coding data related to indicators of prevention and handling of COVID-19 in 
East Kutai Regency, the world cloud provided a visual reference. Of complex information is conveyed quickly and clearly (DePaolo \& Wilkinson, 2014). The word cloud image results show several keywords present in the steps to prevent the spread and handling of COVID-19, which have been implemented in the East Kutai Regency; this can be seen in picture 5.

Prevention

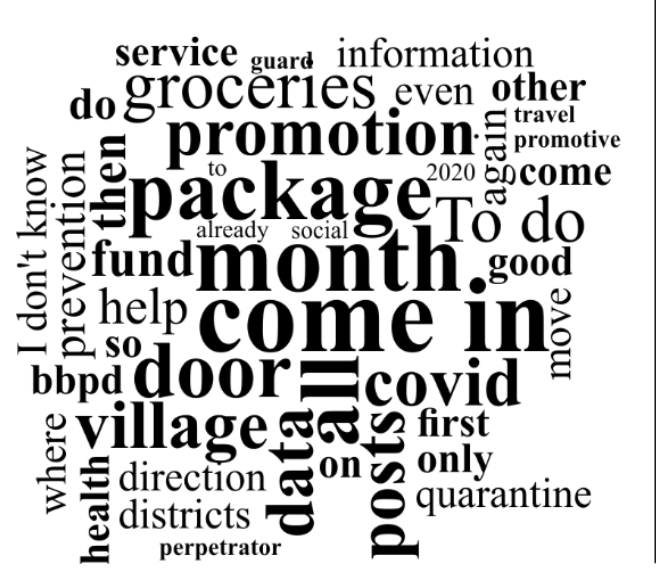

Handling

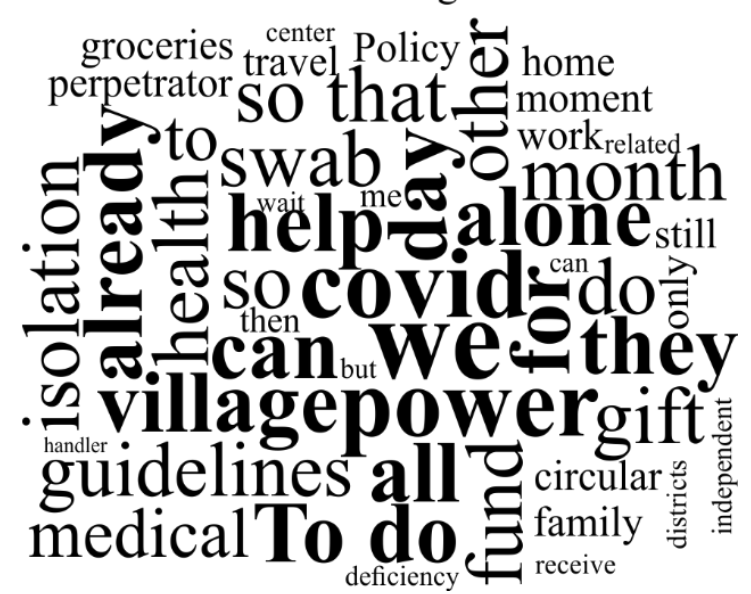

Picture 5. Word Frequency Query in Prevention and Handling in Node Interview

The high intensity of the words "enter," "door," "post," "promotion," and "package" in the world cloud Prevention shows the focus of stakeholders in preventing COVID-19 in East Kutai Regency through restrictions and monitoring of access to activities in and out of the area. The restrictions and supervision that are carried out aim to prevent the increasingly high spread of COVID-19, especially for people who come from the COVID-19 Red Zone area. Posko has been established at several points to control the mobility of the population in East Kutai District, while several posts have been established; namely, 1) Patung Burung Monitor Post; 2) Muara Bengkal Monitoring Post; and 3) Kongbeng Monitoring Post. Furthermore, the said package shows preventive stakeholders' efforts in providing socio-economic assistance to communities affected by the COVID-19 Pandemic in East Kutai Regency.

Meanwhile, the world cloud section of handling shows the intensity of the words "us," "energy," "assistance," "isolation," and "swab" being the words that most often appeared from research sources. It shows that the process of handling COVID-19 carried out by stakeholders is carried out by prioritizing joint handling steps at all levels. Besides, the prevention of spread is also carried out by requiring 14 days of isolation for all people outside the East Kutai Regency area (Arumanto, 2020). For people who have symptoms of COVID19, a Polymerase Chain Reaction (PCR) Swab examination is carried out at the COVID-19 referral hospital in East Kutai Regency; if the test results are positive, intensive care will be carried out in the quarantine room (Sarita, 2020).

Adaptive governance in the face of disasters is one of the keys to successful disaster management (Molenveld \& van Buuren, 2019). The East Kutai Regency Government has taken various adaptation steps to the pandemic situation in its area by giving birth to various policies to deal with the increase in COVID-19 cases in East Kutai Regency. Agility in producing policy regulations that can answer problems in the field requires its presence in responding to crises (Janssen \& van der Voort, 2020). All policies made by the East Kutai Regency Government cannot be separated from the policy references that have been issued by the Central Government and the Provincial Government of East Kalimantan. Some of the policy regulations that have been made can be seen in the following table 5: 
Table 5. East Kutai Regency Policy in Dealing with the COVID-19 Pandemic

\begin{tabular}{|c|c|}
\hline No & Policy \\
\hline 1 & 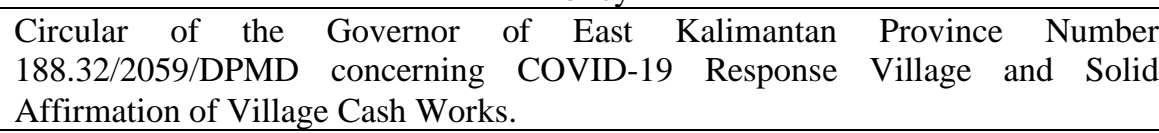 \\
\hline 2 & $\begin{array}{l}\text { Decree of the Regent of East Kutai Number } 443.2 / \text { K.188/2020 concerning the } \\
\text { Determination of The Status of Extraordinary Events With Certain Emergencies, } \\
\text { Emergency Of Corona Disease Outbreak } 2019 \text { (COVID-19) in East Kutai } \\
\text { Regency. }\end{array}$ \\
\hline 3 & $\begin{array}{l}\text { Decree of the Regent of East Kutai Number } 443.2 / K .228 / 2020 \text { concerning the } \\
\text { Determination of Emergency Response Status for Non-Natural Disasters } \\
\text { Coronavirus Disease } 2019 \text { (COVID-19) in East Kutai Regency. }\end{array}$ \\
\hline 4 & $\begin{array}{l}\text { Decree of the Regent No. } 443.2 / \text { K.214/2020 concerning the Establishment of a } \\
\text { Task Force to Accelerate the Handling of Corona Virus Disease } 2019 \text { (COVID- } \\
\text { 19) in East Kutai Regency. }\end{array}$ \\
\hline 5 & $\begin{array}{l}\text { Circular of the Regent of East Kutai Regency Number 140/187/PEMDES. DPMD } \\
\text { on Accelerating COVID-19 Response Village Fund Response and Village Fund } \\
\text { BLT Distribution. }\end{array}$ \\
\hline 6 & $\begin{array}{l}\text { East Kutai Regent Circular Number 188.32/130/DPMDes concerning COVID-19 } \\
\text { Response Village and Solid Affirmation of Village Cash Works. }\end{array}$ \\
\hline 7 & $\begin{array}{l}\text { East Kutai Regent Regulation Number } 32 \text { of } 2020 \text { concerning the Application of } \\
\text { Discipline and Law Enforcement of Health Protocols as an Effort to Prevent and } \\
\text { Control Corona Virus Disease } 2019 \text {. }\end{array}$ \\
\hline 8 & $\begin{array}{l}\text { East Kutai Regent Circular Number: 366/668/PB. COVID-19/CI/2020 on Curfew } \\
\text { and Centralized Quarantine. }\end{array}$ \\
\hline
\end{tabular}

Source: Processed by Author

The policies that have been implemented above illustrate the adaptive management activities carried out by the East Kutai Regency Government in responding to the handling of the COVID-19 Pandemic. This is shown by the agility of the East Kutai Regency government in producing regional regulations that make it easy for related parties to mitigate the COVID19 health disaster in 2020. In addition, it is also known that in establishing these regional regulations, the East Kutai Regency Government carries out participatory decision-making, involving various parties to formulate regulations that are born in a health emergency. The participatory involvement of various parties in formulating policy regulations in the East Kutai Regency during the disaster period provides an excellent opportunity in presenting solutions for all sectors affected by the problems being faced (Hurlbert \& Gupta, 2016; Lei et al., 2015). The regional regulations produced above include increasing the health emergency status in East Kutai Regency, forming a task force for handling COVID-19, and village budget management policies for social assistance for affected village communities.

Furthermore, imposing discipline and law enforcement are also efforts of the local government East Kutai Regency to implement health protocols in daily activities. Activity restrictions during the curfew and centralized quarantine in several regions or regions will also be enforced if COVID-19 transmission is found in the area. Local governments in implementing adaptive governance are considered more sensitive (Hong \& Lee, 2018), so they can react more agile in responding to disasters that occur through the resulting policies. Each region has a defined policy framework for the situation at hand to respond to adaptive governance in a disaster (Ruane, 2020). For that reason, East Kutai Regency has made a derivative policy from the policies for handling COVID-19 in the Central Government, which have been adjusted to the pandemic situation in a certain region. 


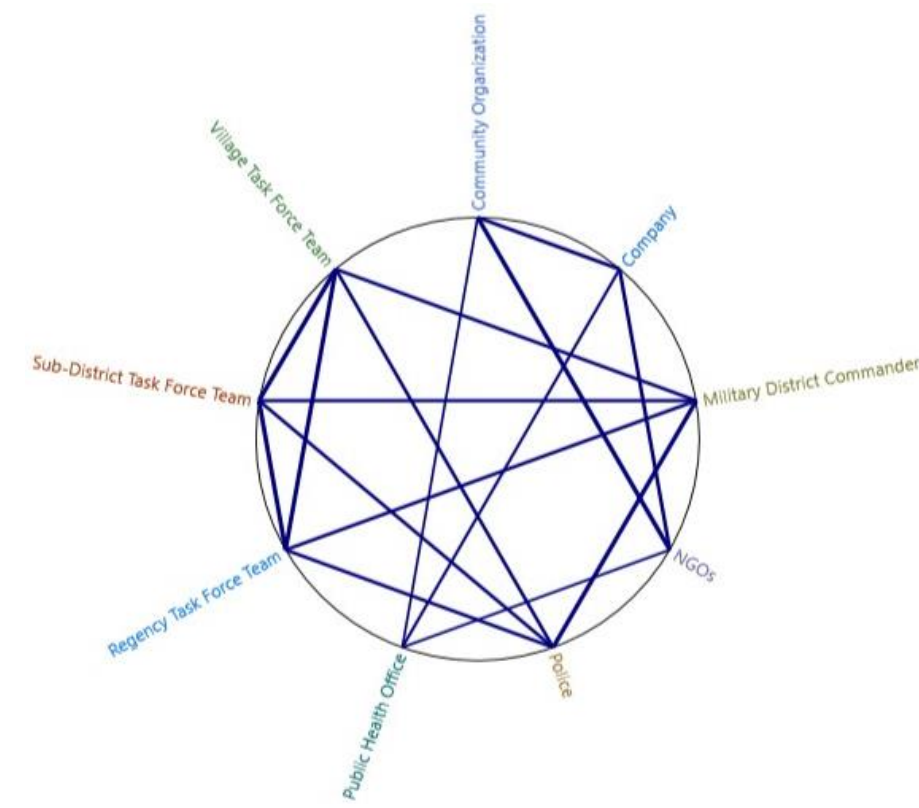

Photo: Nvivo 12 Plus

Picture 6. Related parties in the prevention and handling of the COVID-19

Picture 6 shows the network of agencies involved in handling the COVID-19 pandemic in the East Kutai Regency. These agencies' presence emerged from the processing of the interview manuscripts for the five research sources that the researcher had conducted. The nine agencies play an active role in the mitigation process of the COVID-19 pandemic disaster in East Kutai Regency, namely the 1) Health Service; 2) Police, 3)Military District Command; 4) District Task Force Team; 5) Sub-District Task Force Team; 6) Village Task Force Team; 7) Community Organizations; 8) Community Social Institutions (NGOs); 9) as well as companies in East Kutai District. The active involvement of the nine agencies was shown from the steps to prevent the spread of COVID-19 to the process of handling people affected by the pandemic both healthily, economically, and socially.

The mutually supportive relationship between the above agencies is indicated by a line connected between agencies; the thicker the line created shows, the higher level of interaction between agencies during the COVID-19 disaster management period in East Kutai Regency. If we look carefully at the thick line that appears, there are between the District Task Force Team, the Sub-District Task Force Team, and the Village Task Force Team, connected by a massive thick line. This shows that between the Task Force Teams there are handling activities that are related, this is, of course, the case because the Task Force Team is formed with a tiered vertical structure so that what is the decision on the handling policy that the District Task Force Team has decided will be carried out by the existing levels. Under him, namely the Sub-District Task Force Team and the Village Task Force Team.

Apart from the Task Force Team, there is also a strong relationship between the Police and the Military District Command. Based on the interview results, this strong relationship occurred because the Police and the Military District Command had interrelated roles in securing and appealing disciplinary health protocols to the people in East Kutai District or people who wanted to enter the East Kutai area guarding the post. Available monitoring post. Furthermore, the task force's composition also consists of the Police and District Military Command. The interrelated relationship with the Task Force Teams at all levels appears in picture 7 . 
The participation of community organizations, NGOs, and companies in the East Kutai District is also enjoyable to explore. The participation of parties outside government stakeholders indicates that collaborative adaptive governance occurs at the government and community levels. Based on the interview results, the community organizations that handled the pandemic in East Kutai Regency were Muhammadiyah and Nahdatul Ulama (NU) and other community organizations.

Adaptive governance provides convenience and agility in disaster management (Huitema et al., 2009). Its presence then played an essential role in responding to the COVID-19 pandemic situation the East Kutai Regency faced. The active involvement of five agencies in the organizational network, then creating mutually supportive relationships in preventing and handling COVID-19, shows the importance of effective government in dealing with crises. Chaffin et al. (2014) revealed that the involvement of organizational networks through actors who play a role in pursuing certain situations is a prerequisite for adaptive governance in creating the desired condition. This can be seen from the involvement of each of those agencies in handling the COVID-19 pandemic in the East Kutai Regency. Besides, Smith \& Lawrence (2018) also explain all parties' participation in disaster management through good collaboration in making the disaster management process during a disaster and after a disaster occurs.

Regarding the policies produced in handling the COVID-19 pandemic have also become the East Kutai Regency government's primary concern. By presenting responsive and massive policies, massive in this case is intended for policy products produced by all areas affected by disasters through various institutions involved in the disaster mitigation process. Hurlbert \& Gupta (2016) stated that disaster management requires related policies to resolve problems that can be resolved with various policies made. Furthemore, Naomi Aoki (2016) said the central government's role in disaster management focuses on crucial roles as financiers while other parties at all levels, both central and regional, from profit-oriented to non-profit, consciously and organically work together to form semi-autonomous governance arrangements of different scales, so that they complement each other in mitigating disasters. This is also shown in the picture above, where various parties' involvement in responding to pandemic disasters is present in East Kutai Regency.

As Khan et al. (2021) have said that the optimal pandemic management strategy is to filter the set of organized networks that can provide the most effective results on a massif scale, which is why adaptive response strategies are needed to align the network of old organizations and new organizational networks in the handling of the COVID-19 pandemic. This issue also needs to be optimized again in East Kutai Regency to handle the COVID-19 Pandemic among the mentioned nine agencies that can run optimally. So that, ultimately policies in adaptive governance become a space to ensure that responsibility, participation, and collaboration become a more robust focus during and after disasters occur (Smith \& Lawrence, 2018).

\section{E. CONCLUSION}

The condition of health facilities in the East Kutai Regency is good; the statement is based on the distribution of health facilities needed by the public health (Puskesmas) evenly in all sub-districts and the availability of four hospitals in the East Kutai Regency which are also the COVID-19 Referral Hospitals. The situation of the development of the COVID-19 pandemic in East Kutai Regency continues to increase recorded today East Kutai Regency is classified as an area with red zone status that is classified as an area with a high rate of COVID-19 transmission and occupies the fourth position of all districts/cities in East Kalimantan Province. The COVID-19 risk map released by the Central Government shows 
the East Kutai Regency category of moderate risk by showing the area described as the color "Orange" on the map.

In realizing adaptive governance, the Government of East Kutai Regency has demonstrated cooperation in handling between agencies and all levels of society which is a form of adaptive governance implementation in disaster management. The government has widely carried out measures to prevent the spread and handling of COVID-19 and society's agencies and levels. The involvement of Task Force Teams at all levels, Police, Military District Command, Community Organizations, NGOs, and Companies in helping the prevention and handling of the COVID-19 pandemic run by the East Kutai District Health Office is a form of participation and collaboration in the handling of the COVID-19 pandemic health disaster.

With a small area scale, this study shows that the application of adaptive governance by prioritizing agility in responding to disaster crises through the resulting policies and cooperation between institutions and community components shows that this can be done well if it is implemented comprehensively in all sectors involved and affected. The limitations in this study only show how the adaptive governance values that have been presented in handling the COVID-19 pandemic in the East Kutai Regency are based on data from one party, namely the government so that in future research it will be more interesting if future researchers can present other perspectives through the point of view of the assessment of the community and other parties.

\section{Contributorship}

The first author contributed to formulating research ideas, conducting research, and analyzing the data-reduction findings that had been processed using NVivo-12 plus software. Furthermore, the second author contributed to processing the interview data in the NVivo 12 Plus software, displaying data, and discussing the results.

\section{REFERENCES}

Al-Hamdi, R., Sakir, S., Suswanta, S., Atmojo, M. E., \& Efendi, D. (2020). Penelitian Kualitatif Pegangan Mahasiswa Ilmu Pemerintahan (Queena Ns (Ed.); 01, Oktobe ed.). Pustaka Pelajar.

Andrew, S., Salamonson, Y., \& Halcomb, E. J. (2008). Integrating mixed methods data analysis using NVivo: An example examining attrition and persistence of nursing students. International Journal of Multiple Research Approaches, 2(1), 36-43. https://doi.org/10.5172/mra.455.2.1.36

Aoki, N. (2016). Adaptive governance for resilience in the wake of the 2011 Great East Japan Earthquake and Tsunami. Habitat International, 52, 20-25. https://doi.org/10.1016/j.habitatint.2015.08.025

Arumanto, W. (2020). Kutai Timur berlakukan isolasi bagi karyawan perusahaan usai cuti. Kaltim.Antaranews.Com. https://kaltim.antaranews.com/berita/74468/kutai-timurberlakukan-isolasi-bagi-karyawan-perusahaan-usai-cuti

BPS Kutai Timur. (2019). Indikator Kesejahteraan Rakyat Kabupaten Kutai Timur 2019/2020. In BPS Kutai Timur.

BPS Kutai Timur. (2021). Kabupaten Kutai Timur Dalam Angka 2021. BPS Kutai Timur, 1, $1-404$.

Brandão, C. (2015). P. Bazeley and K. Jackson, Qualitative Data Analysis with NVivo (2nd ed.). Qualitative Research in Psychology, 12(4), 492-494. https://doi.org/10.1080/14780887.2014.992750

Brunner, R. D. (2010). Adaptive governance as a reform strategy. Policy Sciences, 43(4), 
301-341. https://doi.org/10.1007/s11077-010-9117-z

Cahyanti, A. N., \& Purnama, B. E. (2017). Pembangunan Sistem Informasi Manajemen Puskesmas Pakis Baru Nawangan. Speed Journal - Sentra Penelitian Engineering Dan Edukasi, 4(4), 17-21. https://doi.org/10.3112/SPEED.V4I4.893

Chaffin, B. C., Gosnell, H., \& Cosens, B. A. (2014). A decade of adaptive governance scholarship: Synthesis and future directions. Ecology and Society, 19(3). https://doi.org/10.5751/ES-06824-190356

Chen, E., Lerman, K., \& Ferrara, E. (2020). Tracking social media discourse about the COVID-19 pandemic: Development of a public coronavirus Twitter data set. JMIR Public Health and Surveillance, 6(2). https://doi.org/10.2196/19273

Covid19.go.id. (2021). Peta Risiko. Covid19.Go.Id. https://covid19.go.id/peta-risiko covid19.kaltimprov.go.id. (2021). Kaltim Tanggap Covid-19. Covid19.Kaltimprov.Go.Id. https://covid19.kaltimprov.go.id/

Creswell, J. W., \& Poth, C. N. (2016). Qualitative inquiry and research design: Choosing among five approaches. Sage Publications. https://books.google.co.id/books?hl=id\&lr=\&id=DLbBDQAAQBAJ\&oi=fnd\&pg=PP1 $\& \mathrm{dq}=$ creswell $+2013+$ qualitative + inquiry \&ots $=-$ ho47dMSSz\&sig=GKzTi9tUg7a6jmbGaoDmFsPAsdg\&redir_esc $=y \# v=$ onepage $\& q=c r e$ swell 2013 qualitative inquiry $\& \mathrm{f}=$ false

DePaolo, C. A., \& Wilkinson, K. (2014). Get Your Head into the Clouds: Using Word Clouds for Analyzing Qualitative Assessment Data. TechTrends, 58(3), 38-44. https://doi.org/10.1007/s11528-014-0750-9

Djalante, R. (2012). Review Article: Adaptive Governance and resilience: The role of multistakeholder platforms in disaster risk reduction. Natural Hazards and Earth System Science, 12(9), 2923-2942. https://doi.org/10.5194/nhess-12-2923-2012

DPMPTSP Kabupaten Kutai Timur. (2021). Gambaran Kutai Timur. Dpmptsp.Kutaitimurkab.Go.Id. https://dpmptsp.kutaitimurkab.go.id/profiledaerah/gambaran-kutai-timur

Edwards-Jones, A. (2014). Qualitative data analysis with NVIVO. Journal of Education for Teaching, 40(2), 193-195. https://doi.org/10.1080/02607476.2013.866724

Grindle, M. S. (2004). Good enough Governance: Poverty reduction and reform in developing countries. Governance, 17(4), 525-548. https://doi.org/10.1111/j.09521895.2004.00256.x

Hadiwardoyo, W. (2020). Kerugian Ekonomi Nasional Akibat Pandemi Covid-19. Baskara: Journal of Business and Entrepreneurship, 2(2), 83-92. https://doi.org/10.24853/baskara.2.2.83-92

Handayani, S. (2016). Tingkat Kepuasan Pasien Terhadap Pelayanan Kesehatan Di Puskesmas Baturetno. Profesi (Profesional Islam) : Media Publikasi Penelitian, 14(1), 42. https://doi.org/10.26576/profesi.135

Handayanto, R. T., \& Herlawati, H. (2020). Efektifitas Pembatasan Sosial Berskala Besar (PSBB) di Kota Bekasi Dalam Mengatasi COVID-19 dengan Model SusceptibleInfected-Recovered (SIR). Jurnal Kajian Ilmiah, 20(2), 119-124. https://doi.org/10.31599/jki.v20i2.119

Hasselman, L. (2017). Adaptive management; adaptive co-management; adaptive governance: what's the difference? Australasian Journal of Environmental Management, 24(1), 31-46. https://doi.org/10.1080/14486563.2016.1251857

Holley, C. (2010). Facilitating Monitoring, Subverting Self-Interest and Limiting Discretion: Learning from "New" Forms of Accountability in Practice. Columbia Journal of Environmental Law, 35(1), 127-211.

Hong, S., \& Lee, S. (2018). Adaptive governance and decentralization: Evidence from 
regulation of the sharing economy in multi-level governance. Government Information Quarterly, 35(2), 299-305. https://doi.org/10.1016/j.giq.2017.08.002

Huitema, D., Mostert, E., Egas, W., Moellenkamp, S., Pahl-Wostl, C., \& Yalcin, R. (2009). Adaptive water governance: Assessing the institutional prescriptions of adaptive (co)management from a governance perspective and defining a research agenda. Ecology and Society. https://doi.org/10.5751/ES-02827-140126

Hurlbert, M., \& Gupta, J. (2016). Adaptive Governance, Uncertainty, and Risk: Policy Framing and Responses to Climate Change, Drought, and Flood. Risk Analysis, 36(2), 339-356. https://doi.org/10.1111/risa.12510

Janssen, M., \& van der Voort, H. (2016). Adaptive Governance: Towards a stable, accountable, and responsive government. Government Information Quarterly, 33(1), 15. https://doi.org/10.1016/j.giq.2016.02.003

Janssen, M., \& van der Voort, H. (2020). Agile and adaptive governance in crisis response: Lessons from the COVID-19 pandemic. International Journal of Information Management, 55(June), 102180. https://doi.org/10.1016/j.ijinfomgt.2020.102180

Junaedi, D., Arsyad, M. R., Norman, E., Romli, M., \& Salistia, F. (2020). Dampak Pandemi Covid-19 terhadap Stabilitas Moneter Indonesia. Al-Kharaj : Jurnal Ekonomi, Keuangan \& Bisnis Syariah, 3(1), 17-36. https://doi.org/10.47467/alkharaj.v3i1.149

Kementrian Kesehatan RI. (2020a). 136 Kabupaten/Kota Masuk Dalam Zona Kuning. Kemkes.Go.Id. https://www.kemkes.go.id/article/view/20062600002/136-kabupatenkota-masuk-dalam-zona-kuning.html

Kementrian Kesehatan RI. (2020b). Jubir COVID-19: Kecepatan Tes Berdasarkan Gambaran Epidemologi Tiap Daerah. Kemkes.Go.Id. https://www.kemkes.go.id/article/view/20062000003/jubir-covid-19-kecepatan-tesberdasarkan-gambaran-epidemologi-tiap-daerah.html

Khan, M., Roy, P., Matin, I., Rabbani, M., \& Chowdhury, R. (2021). An adaptive governance and health system response for the COVID-19 emergency. World Development, 137. https://doi.org/10.1016/j.worlddev.2020.105213

Lei, Y., Liu, C., Zhang, L., Wan, J., Li, D., Yue, Q., \& Guo, Y. (2015). Adaptive governance to typhoon disasters for coastal sustainability: A case study in Guangdong, China. Environmental Science and Policy, 54, 281-286. https://doi.org/10.1016/j.envsci.2015.07.016

Loilatu, M. J., Irawan, B., Salahudin, S., \& Sihidi, I. T. (2021). Analisis fungsi twitter sebagai media komunikasi transportasi publik. Jurnal Komunikasi, 13(1), 2021. https://doi.org/10.24912/jk.v13i1.8707

Molenveld, A., \& van Buuren, A. (2019). Flood risk and resilience in the Netherlands: In search of an adaptive governance approach. Water (Switzerland), 11(12), 1-20. https://doi.org/10.3390/w11122563

Muhtarom, Murtianto, Y. H., \& Sutrisno. (2017). Thinking process of students with highmathematics ability: (a study on QSR NVivo 11-assisted data analysis). International Journal of Applied Engineering Research, 12(17), 6934-6940.

Nasruddin, R., \& Haq, I. (2020). Pembatasan Sosial Berskala Besar (PSBB) dan Masyarakat Berpenghasilan Rendah. SALAM: Jurnal Sosial Dan Budaya Syar-I, 7(7). https://doi.org/10.15408/sjsbs.v7i7.15569

Olivia, S., Gibson, J., \& Nasrudin, R. (2020). Indonesia in the Time of Covid-19. Bulletin of Indonesian Economic Studies, 56(2), 143-174. https://doi.org/10.1080/00074918.2020.1798581

Pemkab. Kutai Timur. (2021). Sejarah. Kutaitimurkab.Go.Id. https://www.kutaitimurkab.go.id/page/profile/1 
Pratama, O. (2020). Konservasi Perairan Sebagai Upaya menjaga Potensi Kelautan dan Perikanan Indonesia. https://kkp.go.id/djprl/artikel/21045-konservasi-perairan-sebagaiupaya-menjaga-potensi-kelautan-dan-perikanan-indonesia

Putsanra, D. V. (2020). Arti PSBB yang Dibuat untuk Cegah Penyebaran Corona di Indonesia. $\quad$ https://tirto.id/arti-psbb-yang-dibuat-untuk-cegah-penyebaran-corona-diindonesia-eMXT

Rijke, J., Brown, R., Zevenbergen, C., Ashley, R., Farrelly, M., Morison, P., \& van Herk, S. (2012). Fit-for-purpose Governance: A framework to make adaptive governance operational. Environmental Science and Policy, 22, 73-84. https://doi.org/10.1016/j.envsci.2012.06.010

Ruane, S. (2020). Applying the principles of adaptive governance to bushfire management: a case study from the South West of Australia. Journal of Environmental Planning and Management, 63(7), 1215-1240. https://doi.org/10.1080/09640568.2019.1648243

Samudro, E. G., \& Madjid, M. A. (2020). Pemerintah Indonesia Menghadapi Bencana Nasional Covid -19 Yang Mengancam Ketahanan Nasional. Jurnal Ketahanan Nasional, 26(2), 132. https://doi.org/10.22146/jkn.56318

Saputra, H., \& Salma, N. (2020). Dampak PSBB dan PSBB Transisi di DKI Jakarta dalam Pengendalian COVID-19. Media Kesehatan Masyarakat Indonesia, 16(3), 282-292. https://doi.org/10.30597/mkmi.v16i3.11042

Sarita, M. (2020). Lebih 500 Warga Kutai Timur Ikut Tes Swab Gratis di Mobile PCR. Tribunkaltim.Co. https://kaltim.tribunnews.com/2020/11/25/lebih-500-warga-kutaitimur-ikut-tes-swab-gratis-di-mobile-pcr?page $=2$

Shahbudin, M. S. I. (2020). Kepanikan Pengguna Media Sosial Terhadap Virus Covid 19. PENDETA Journal of Malay Language, Education, and Literature, 11, 1-10. http://ojs.upsi.edu.my/index.php/PENDETA/article/view/3579

Smith, K., \& Lawrence, G. (2018). From disaster management to adaptive governance? Governance challenges to achieving resilient food systems in Australia. Journal of Environmental Policy and Planning, 20(3), 387-401. https://doi.org/10.1080/1523908X.2018.1432344

Syafrida, S. (2020). Bersama Melawan Virus Covid 19 di Indonesia. SALAM: Jurnal Sosial Dan Budaya Syar-I, 7(6). https://doi.org/10.15408/sjsbs.v7i6.15325

Syah, R. H. (2020). Dampak Covid-19 pada Pendidikan di Indonesia: Sekolah, Keterampilan, dan Proses Pembelajaran. SALAM: Jurnal Sosial Dan Budaya Syar-I, 7(5). https://doi.org/10.15408/sjsbs.v7i5.15314

Telaumbanua, D. (2020). Urgensi Pembentukan Aturan Terkait Pencegahan Covid-19 di Indonesia. 12(1), 59-70.

Tuwu, D. (2020). Kebijakan Pemerintah Dalam Penanganan Pandemi Covid-19. Journal Publicuho, 3(2), 267. https://doi.org/10.35817/jpu.v3i2.12535

Walch, C. (2019). Adaptive governance in the developing world: disaster risk reduction in the State of Odisha, India. Climate and Development, 11(3), 238-252. https://doi.org/10.1080/17565529.2018.1442794

Worldmeter. (2021). Covid-19 https://www.worldometers.info/coronavirus/

Wyborn, C. A. (2015). Connecting knowledge with action through coproductive capacities: Adaptive governance and connectivity conservation. Ecology and Society, 20(1). https://doi.org/10.5751/ES-06510-200111 